\title{
高溶融張力 PP のメルトレオロジー挙動と発泡成形
}

杉本 昌 隆 ${ }^{* 1} \cdot$ 下 村 洋 三*2

\section{1.はじめに}

三大合成樹脂の一つであるポリプロピレン（PP）はそ の誕生から 40 年を超える歴史の中で重合技術などの目覚 ましい技術革新を受け，その優れた特性たとえば汎用プラ スチックの中で最も軽く, 剛性, 耐熱性, 耐薬品性などに 優れることから，現在も高い成長を続けている樹脂の 1 つ である。用途としては軟質の分野から汎用エンプラに近い 分野まで幅広く用いられており, 生活に密着した日用品か ら, 家電, 自動車, 工業部品として幅広く使用されている. PP はその優れた特性に加えリサイクル性も有することか ら, 今後もさらなる成長が期待されている樹脂の 1 つであ ろう。

高分子の発泡は, 1943 年に Dow Chemcal 社でポリスチ レン（PS）が初めて工業化され, その後, 熱可塑性樹脂 ではPS に加えてポリエチレン（PE）が企業化されている. 現在でも高分子樹脂を発泡させたものの原料として最も多 用されているのはPSである. PS 発泡体は押出発泡プロ セスによって発泡シート，それを食品用途として成形した 発泡トレイ，建築用材としてとしての断熱ボードなどとし て多用されている。

また，オレフィン樹脂の中では低密度ポリエチレン (LDPE) が発泡成形プロセスの開発当初よりフッ化炭素 などの発泡剂を用いて，おもに緩衝材用途を目的として押 出発泡製品に用いられてきた. LDPE はその分子構造にお いて，長鎖分岐構造を有しており伸長流動においていわゆ るひずみ硬化性を発現することや，直鎖状 PEに比べて結 晶性が低く融点近傍での粘度変化が緩やかであるため押出 発泡化が可能であるとされている.

しかし,PSやPE は断熱性, 耐熱性にそしく,また, PS は 耐薬品性が不足しており，これらの改良が発泡製品におい ても同様に求められている。一方, PP は結晶性樹脂であ り, 非晶性樹脂の PS や結晶性樹脂の PE と比較しても融 点が高く, 熱的に安定であり, 機械的な性質も優れている.

近年, PP 発泡の製品開発が活発になってきた。この理

\footnotetext{
${ }^{* 1}$ Sugimoto, Masataka

チッソ石油化学(侏) 高分子研究所

市原市五井海岸 5-1（和290-0058）

*2 Shimomura, Yozo

チッソ侏) 機能性樹脂部

千代田区丸の内 2-7-3 東京ビル 4 F（テ100-8333）

2000.12. 25 受理
}

由として，上述の PP が有する特性の実用特性とそのリサ イクル性があげられるであろう。 2000 年 4 月にプラス チック製容器包装のリサイクルに関する法律が施行され, 関連する業界はごみの減量化とリサイクルへの対応が求め られるようになった，また，現代の食生活の変化に伴い， 電子レンジで温めて調理するような簡易食品包装が増えて いるが，このような分野ではレンジアップに対応する耐熱 性が必要となる。

PP はこれらの要求に応えることのできる樹脂の一つで ある。もし，PPの発泡成形プロセスにおいて，発泡倍率, 独立気泡率，あるいは形状等を制御し発泡体を得ることが できれば, その軽量性, 構造体としての特性, 生産性等を 生かして包装材，断熱材，緩衝材などの多様な用途を見い だせる可能性がある.

しかし，一般にPPはその発泡体を得るのが難しい樹脂 である．その原因として，PP が PSに比べて発泡成形が 可能な温度範囲が極めて狭いことによるものとされてきた 非晶性樹脂である PS は図 1 に示すように溶融時の温度変 化に対して, 溶融粘度の変化が比較的緩やかであるために 発泡しやすい樹脂とされ1)，前述のように発泡成形プロセ スが開発された当初から原料樹脂の筆頭にあげられてきた

発泡成形に抢いて，そのセルの成長，または固定化段階 において伸長流動を受ける。伸長流動下におけるいわゆる ひずみ硬化性は，これらの段階において重要な役割を果た すものと考えられている. しかし，一般的にPS は伸長流 動下でのひずみ硬化性がそれほど強い樹脂ではない。また 最近では各種樹脂のガス溶解度と溶解時の特性についての 研究が進みつつあるが, PS の発泡ガス溶解度と成形性を 結び付けるのは難しいのかもしれない吕, 。 これらのこと

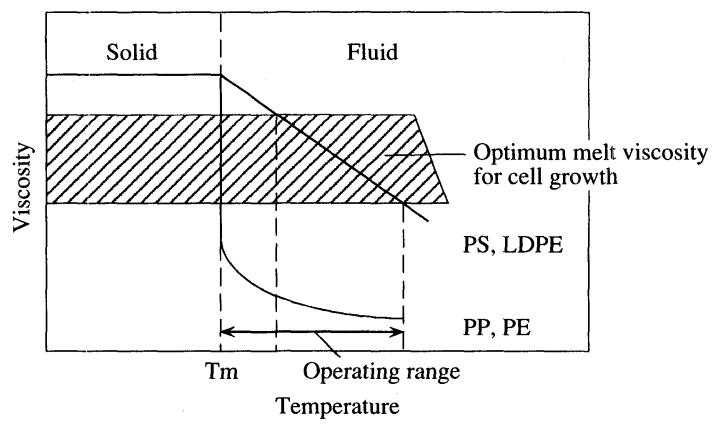

Fig. 1 Schematic illustration of foaming window 
から，PSの良好な発泡成形性は，図１に示したような適 正加工範囲が広いことや，ガスを含有したときの $\mathrm{Tg}$ の変 化量にも影響されているのではないかといわれている4).

一方, 結晶性樹脂である PP は, 融点近傍における温度 変化に対して流動性が敏感に変化してしまう。すなわち融 点以上では粘度は急激に低くなり, 逆に融点以下では結晶 化温度に近づくと急激に粘度が上昇してさらには結晶化が 生じてしまう。このため, PP の加工範囲は PSなどと比 べて非常に狭くなってしまう.

ここで，融点以上での PP の流動性の改良に目を向けて みる. PP の流動性の特徴として, 代表的なポリオレフィ ンの一つである高密度ポリエチレン（HDPE）などに比較 しても溶融張力が低く，自由表面を有するような成形加工 法では成形性に劣ると認識されてきた。この最大の原因は 伸長流動下におけるひずみ硬化性が非常に小さいことが挙 げられよう。

これまでにPP の溶融張力を向上させる方法としては, (1)PPの MFR を低下させる（高分子量化する)，(2)多段 重合等の方法で PP の分子量分布を広くする5)，(3)電子線 照射や造粒変成法等により架橋化したり，長鎖分岐・グラ フト鎖を生成させる ${ }^{6 / 10)},(4)$ 溶融張力が高い他樹脂と複 合化する ${ }^{11}$ ，等の方法がとられてきている．しかし，高分 子量化や分子量分布の広幅化では成形性が低下したり，溶 融張力やひずみ硬化性の向上が大きくは期待できない等の 問題がある．また，架橋させたり，他樹脂と複合化する場 合には，材料の高コスト化と共に，リサイクルした場合に 不具合等（ゲルの発生, 溶融張力の低下など）が生じてい る.

樹脂の溶融特性を改良するもう一つの方法として，(5) 通常の分子量をもつポリマーに少量の超高分子量成分を添 加する方法がある. 小山と石塚ら ${ }^{122}$ は Lodge 型の構成方程 式を用いてポリブテン-1（PB-1）の伸長粘度特性につい て検討を行っている. 比較的狭い緩和スペクトル $\left(10^{-2} \sim\right.$ $10^{2} \mathrm{~s} ） て ゙ は$ 伸長粘度の線形領域を表すのみであるが，これ に少量の長時間緩和モードを考慮することで非線形領域ま でを再現できることを明らかにしている。このような伸長 流動における非線形挙動に関する予測は, 均一系ポリマー ブレンドなどによって実験的にも支持されるようになっ $た^{(13), 14}$.

PP に関しては，重合過程において溶融レオロジー特性 を有効に改良することは困難であるとされてきた，当社で は独自の重合・触媒技術を用いて重合段階で溶融張力を向 上させた高溶融張力 PP (Reactor-made HMSPP) の開発 に成功し，上市するに到った。この発泡成形用の高溶融張

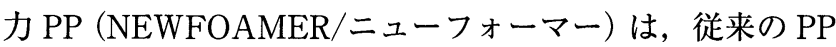
に対してそのすぐれた特性を損なうことなく流動特性が改 良されている．また，これまで報告されている他の樹脂に 比べても興味ある流動特性を有しているといえるかも知れ ない.

樹脂の押出発泡プロセス特に物理発泡成形は，(1) 発泡 剤ガスの溶解過程，(2)気泡核の生成，(3) 気泡の成長，(4) 気泡の固定化 (安定化), により構成されるものと考えら れている ${ }^{15)}$. 樹脂中に溶解したガスは樹脂粘度を低下させ る可塑効果があるが，これが発泡剂として膨張しセルを形
成する際，樹脂中に溶けているガスが気泡核に拡散するこ とにより粘度を上昇させる。 さらに，この気泡の成長段階 では溶融樹脂はガスの断熱膨張や外気との接触により冷却 を受ける. また，このセルの膨張過程で樹脂は伸長変形を 受ける．伸長流動下でのひずみ硬化性を有する樹脂では, あるひずみにおいて伸長粘度が急激に上昇することによっ てセルの変形の安定化が図られるものと考えられる.この 様にセルの固定化はいくつかの因子によって図られること が考えられるが，すべて取り上げるのは筆者らの手に負え るものではなく，あらかじめご容赦いただきたい.

ここでは高溶融張力 PP について，レオロジー特性にし ぼって従来 PP と比較しながら取り上げ，さらにこの高溶 融張力 PP を発泡成形に適用した場合について簡単にご説 明させていただきたい。

\section{2. 高溶融張力 PP のレオロジー特性}

\section{1 試料}

代表的な試料として, 従来 $\mathrm{PP}$ を $\mathrm{PP}-\mathrm{A}$, 高溶融張力 $\mathrm{PP}$ を $\mathrm{PP}-\mathrm{B}$ および $\mathrm{PP}-\mathrm{C}$ とする. $\mathrm{PP}-\mathrm{B}$ および $\mathrm{PP}-\mathrm{C}$ は重合・ 触媒技術により，リアクター中で長時間緩和成分を賦与し たものである。これらのメルトフローレート (MFR), 重 量平均分子量 $\left(\bar{M}_{W}\right)$, 融点について表 1 にまとめた. $\mathrm{PP}-$ $\mathrm{B}$ および $\mathrm{PP}-\mathrm{C}$ は平均分子量, 融点等について従来 $\mathrm{PP}$ で ある $\mathrm{PP}-\mathrm{A}$ と特に差異は認められない。

\section{2 測定方法}

\subsection{1 溶融張力測定}

溶融張力測定には東洋精機侏製キャピログラフを用い た. $230{ }^{\circ} \mathrm{C}$ で 5 分間溶融後, $2.095 \mathrm{~mm}$ のオリフィスから $20 \mathrm{~mm} / \mathrm{min}$ の引き取り速度における張力から求めた。 ス ウェル比は溶融張力測定と同条件で溶融物を $30 \mathrm{~mm}$ 程度 押し出し, 固化したときの直径とオリフィス径の比から求 めた.

\subsection{2 動的粘弾性}

せん断流動下での動的粘弾性測定には，DSR-200（レオ メトリックス侏製）を用いた．同測定には直径 $25 \mathrm{~mm}$ の パラレルプレートが用いられた. 周波数範囲は $10^{-3} \sim 10^{2} \mathrm{rad}$

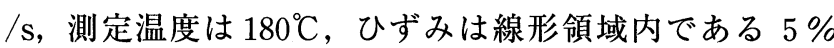
とした。サンプルは $230^{\circ} \mathrm{C}$ で 10 分間溶融し, 約 $10^{\circ} \mathrm{C}$ の冷 却温度で $2 \mathrm{~mm}$ の厚さに圧縮成形された. 異なる温度で測 定した $G^{\prime}, G ”$ 曲線から，基準温度へ横移動によって重ね 合わすことで合成曲線（マスターカーブ）を得ることがで きる ${ }^{16)}$ ここととき移動因子 $a_{T}$ は次の Arrhenius 型の次 式によって表される。

$$
\ln a_{T}=A+\frac{E_{V}}{R T}
$$

Table 1 Characteristics of High-Melt-Strength PP

\begin{tabular}{cccc}
\hline Code & $\begin{array}{c}\text { MFR } \\
\mathrm{g} / 10 \mathrm{~min}\end{array}$ & $\begin{array}{c}\overline{\mathrm{M}} \mathrm{w} \\
/ 10^{5}\end{array}$ & $\begin{array}{c}\mathrm{Tm}^{\mathrm{a}} \\
\left({ }^{\circ} \mathrm{C}\right)\end{array}$ \\
\hline PP-A & 0.4 & 5.4 & 166 \\
PP-B & 0.3 & 5.0 & 167 \\
PP-C & 0.4 & 5.0 & 166 \\
\hline
\end{tabular}

$\mathrm{a}$ :Melting temperature obtained from DSC thermogram 
ここで, $E_{V}$ は流動の活性化エネルギー, $R$ は気体定数, $T$ は絶対温度, $A$ は実験定数である.

\subsection{3 クリープ測定}

動的粘弾性と同じ装置, 治具を用いて $180^{\circ} \mathrm{C} て ゙$ 測定を 行った.クリープ測定は 10 800 Pa の様々な応力下で行 われた.

\subsection{4 階段状応力緩和測定}

応力緩和測定は，ひずみ制御型レオメーター（ARES, レオメトリックス侏製) を用いた。測定は， $25 \mathrm{~mm}$ 平行 円盤を用いて, ギャップ $1 \mathrm{~mm}$, 温度 $180^{\circ} \mathrm{C}$, ひずみとは $0.3 \sim 6$ の範囲で行った. 応力 $\sigma$ はひずみ $\gamma(0.3 \sim 6)$ を印 加後, 4 桁にわたって測定され, 非線形緩和弾性率 $G(t, \gamma)$ は次式によって求められる.

$$
G(t, \gamma)=\sigma(t, \gamma) / \gamma
$$

各測定において階段状ひずみを与えるのに要した時間は 0.2 秒以下であった. $G(t, r)$ は, パラレルプレート中のひ ずみの不均一性のために Soskey ら ${ }^{17)}$ の方法を用いて補正 を行った。

\subsection{5 一軸伸長粘度測定}

一軸伸長粘度測定用の試料は $2.095 \mathrm{~mm}$ のオリフィスを 持つキャピログラフから $230^{\circ} \mathrm{C}, 5 \mathrm{~mm} / \mathrm{min}$ で押出し, 直 径約 $3 \mathrm{~mm}$, 長さ $30 \mathrm{~mm}$ の棒状の試験片を得た. 残留応 力を除去するため, 測定前に $180^{\circ} \mathrm{C}$ のシリコンオイルバス 中で 10 分間溶融した。一軸伸長粘度測定は Meissner 型 レオメーター18)用いて, $180^{\circ} \mathrm{C}$, 一定ひずみ速度下で行っ た.サンプルの直径変化は CCD カメラとビデオを用いて 記録し, 均一伸長変形の確認と真のひずみ速度の計算を 行った.

\section{3 測定結果と考察}

\subsection{1 溶融張力}

PP-A，PP-B および PP-C の溶融張力測定結果を表 2 に 示した. $\mathrm{PP}-\mathrm{A}$ に対して, $\mathrm{PP}-\mathrm{B}$ は明らかに高い溶融張力 を示した. PP-Cではストランド切れのため測定できな かった. 次に従来 PP と高溶融張力 PPについて, 溶融張 力の MFR 依存性を図 2 に示す．同じMFR で比較すると， 高溶融張力 PP は従来 PP に対して 2 10 倍程度の高い溶 融張力を有することが分かる. また, MFRが増加（分子 量が低下）すると, 従来 PP の溶融張力は大きく低下する が, 高溶融張力 PP はその低下割合が小さい. 図 3 に溶融 張力の温度依存性を示す. 高溶融張力 PP は, 従来 PPに 対して, 温度に対する依存性も低いことがわかる。

\subsection{2 動的粘弾性}

図 4 に PP-A, PP-B と PP-C の動的粘弾性測定結果を示

Table 2 Characteristics of High-Melt-Strength PP

\begin{tabular}{cccc}
\hline Code & $\begin{array}{c}\text { MFR } \\
\mathrm{g} / 10 \mathrm{~min}\end{array}$ & $\begin{array}{c}\mathrm{MS}^{\mathrm{a}} \\
\mathrm{cN}\end{array}$ & $\begin{array}{c}E_{V^{c}} \\
(\mathrm{~kJ} / \mathrm{mol})\end{array}$ \\
\hline PP-A & 0.4 & 4.7 & 38 \\
PP-B & 0.3 & 9.3 & 38 \\
PP-C & 0.4 & n.d. $^{\text {b }}$ & 37 \\
\hline
\end{tabular}

a : Melt strength at $230^{\circ} \mathrm{C}$

$\mathrm{b}:$ not determined owing to rupture of strand $c$ : Activantion enegy of flow
す. 図中, $G^{\prime}$ は貯藏弾性率, $G$ ” は損失弾性率を示す. PP -A は MFR が比較的低く(分子量が高い), 低周波数側で も, 末端流動 ${ }^{16)}\left(G^{\prime} \sim \omega^{2}, G ” \sim \omega\right)$ に達していない.一方, PP-B，PP-Cでは低周波数側の $G^{\prime}$ において第二平坦領域

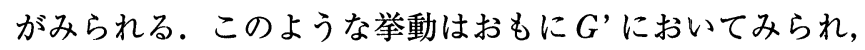
$G ”$ における違いは小さい.

温度を変えて $G^{\prime}, G$ ”を測定した結果から式(1)にした がって求められた流動の活性化エネルギー $E_{V}$ を表 2 に示 した，高い $E_{V}$ は一般的に分岐構造と関連づけられ，変成 処理によって得られる分岐 $\mathrm{PP}$ の $E_{V}$ 值は直鎖 $\mathrm{PP}$ より高

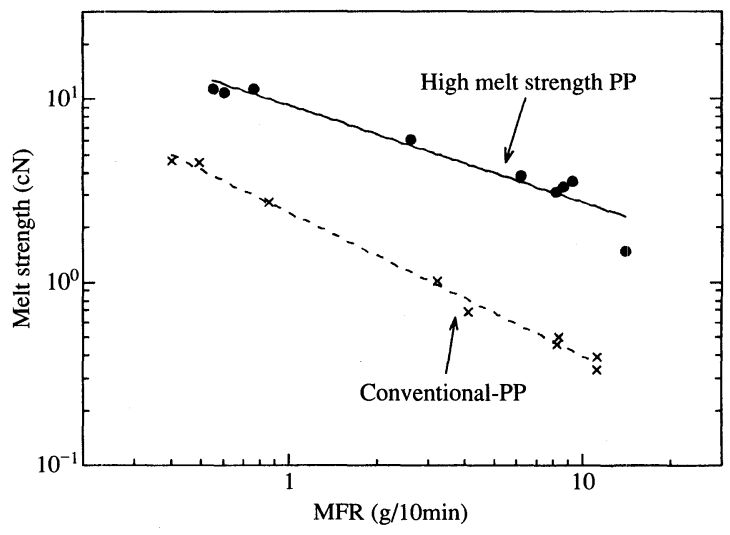

Fig. 2 Variation of melt strength with melt flow rate (MFR) for polypropylene. Sample : $(X)$, conventional PP ; $(O)$, high-melt-strength PP

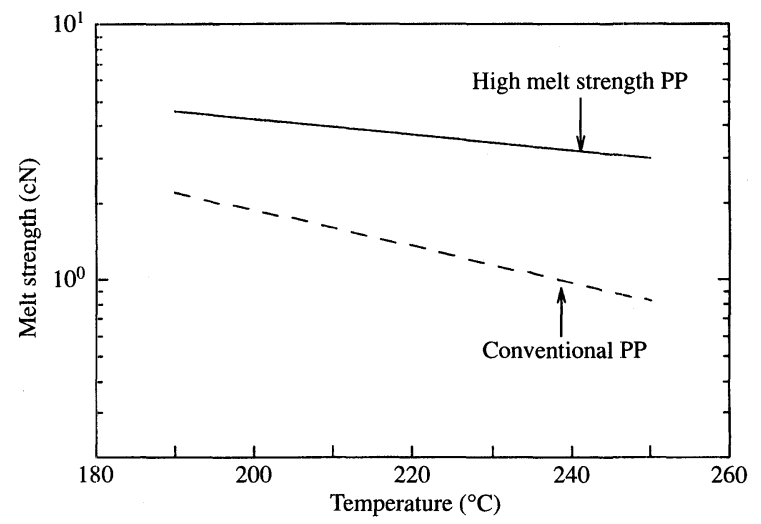

Fig. 3 Variation of melt strength with temperature for high-melt-strength PP and conventional PP

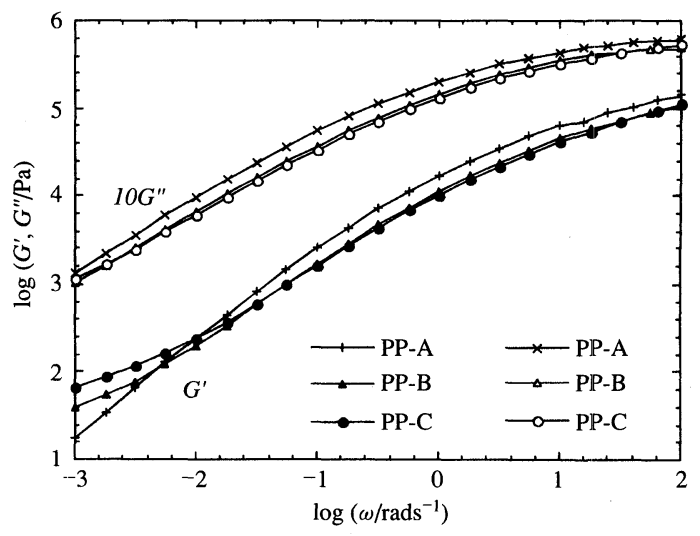

Fig. 4 Storage modulus $G^{\prime}$ and loss modulus $G$ " as a function of frequency at $180^{\circ} \mathrm{C}$ for PP-A, PP-B and PP-C 
いことが報告されている年．しかし，高溶融張力 PP の $E_{V}$ は従来の $\mathrm{PP}$ と同程度である. $\mathrm{PP}-\mathrm{A}, \mathrm{PP}-\mathrm{B}, \mathrm{PP}-\mathrm{C}$ の $G ', G ”$ から緩和時間の分布関数を求めることによって, 粘弾性液体（溶融体）のレオロジーの特徴を表すことがで きる．緩和スペクトルはいろいろな近似式が提案されてい るが, ここでは Tschoegl の二次近似式" ${ }^{20)}$ 用いて離散型 の緩和スペクトル $H(t)$ を求めた。このとき次の式 3,4 を使って $H(t)$ が，実験的に得られた $G^{\prime} ， G ”$ を再現しう るように繰り返し計算から最適な値を決定した。

$$
\begin{aligned}
& G^{\prime}(\omega)=\sum_{i=1}^{N} G_{i} \frac{\omega^{2} \tau_{i}^{2}}{1+\omega^{2} \tau_{i}^{2}} \\
& G^{\prime}(\omega)=\sum_{i=1}^{N} G_{i} \frac{\omega \tau_{i}}{1+\omega^{2} \tau_{i}^{2}}
\end{aligned}
$$

ここで $G_{i}$ は,

$$
G_{i}=H\left(\tau_{i}\right) \Delta \ln \left(\tau_{i}\right)
$$

で表される，PP-B，PP-C の長時間緩和機構は通常 PP の 緩和成分より十分長いものとし，ここでは恣意的に $\tau=10^{5}$ $\mathrm{s}$ と仮定して $H(t)$ を求めた。離散型緩和スペクトルの評 価結果を図 5 に示す. PP-B, PP-C では PP-A では見るこ とのできない非常に長い䌅和時間成分が出現していること が分かる.

\subsection{3 クリープ}

$\mathrm{PP}-\mathrm{A}, \mathrm{PP}-\mathrm{B}$ および $\mathrm{PP}-\mathrm{C}$ について溶融クリープ試験か ら求められた定常粘度 $\eta_{s}$ と 2.3.2 で得られた動的粘度 $\eta^{*}$ を同時にプロットしたものを図 6 に示す，PP-Aについて は, 低せん断速度（角周波数）領域で $\eta_{s}$ と $\eta^{*}$ はほほ一致 しており，これまで報告されている一般的なポリマーと同 じ挙動である. しかし, PP-B拉よびPP-Cでは, $10^{-3}(/ \mathrm{s})$ 以 下で非常に高い粘度を示し, 二段の粘度挙動を示している。

\subsection{4 階段状応力緩和}

PP-A の階段状応力緩和挙動を図 7 に示す. 図 7 におい て，せん断ひずみが小さいとき $G(t, \gamma)$ は $\gamma$ に依存せず, ある $\gamma$ 以上で $G(t, r)$ は $\gamma$ の増加とともに減少し非線形の 緩和弾性率が観察される。このような挙動はこれまで報告 されているものと同様の傾向である ${ }^{21,22)}$.

一方， PP-C の応力緩和挙動を図 8 に示す．短時間領域 $(\mathrm{t}<100 \mathrm{~s})$ における挙動は $\mathrm{PP}-\mathrm{A}$ と同様, 時間とともに

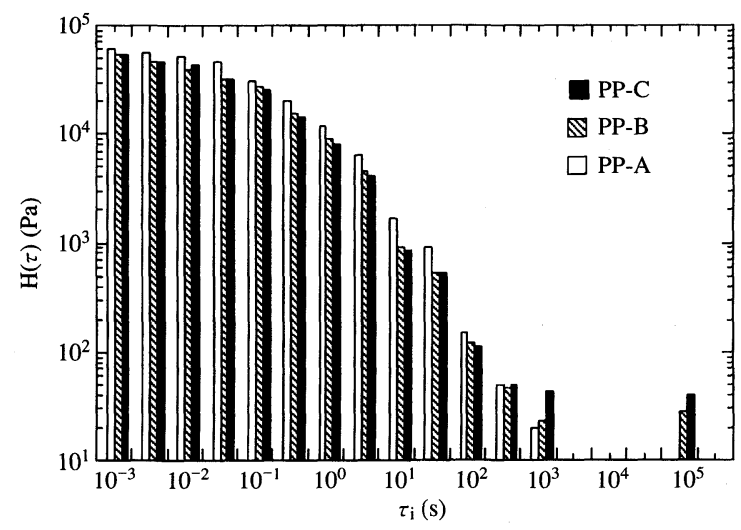

Fig. 5 Discrete relaxation spectra calculated from dynamic tests for PP-A, PP-B and PP-C
単純に減少し，それらは縦軸方向に重ね合わせることがで きる.しかし，長時間では $G(t, r)$ の減少は緩やかになり， $\mathrm{PP}-\mathrm{A}$ とは明らかに異なる緩和機構が観察される.

応力緩和機構をより詳しく検討するため, ダンピング関 数 $h(\gamma)^{23)}$ を次式から求めた.

$$
G(t, \gamma)=G(t) h(\gamma)
$$

ここで, $G(t)$ は線形領域の緩和弾性率である. 図 9 に PP$\mathrm{A}, \mathrm{PP}-\mathrm{B}$ および $\mathrm{PP}-\mathrm{C}$ の $h(\gamma)$ を示す. 図中, 破線は単分 散ポリマーに対する理論值 ${ }^{24)}$ でる. PP-Aの $h(\gamma)$ は一 般的な多分散直鎖ポリマーのそれとほほ同程度である。 PP-B と PP-Cでは, 短時間側の $G(t, r)$ から得られた $h_{f}(\gamma)$ はP-A と同程度であるのに対し, 緩和が緩やかに なる長時間側で得られた $h_{s}(\gamma)$ は, ひずみに対する依存性 が弱い.

\subsection{5 一軸伸長粘度}

次に，伸長流動下での挙動について議論する．前述のよ うに, PP は伸長流動下での急激な粘度上昇, つまりひず み硬化性が非常に弱い樹脂であり, これが, 発泡成形, 真

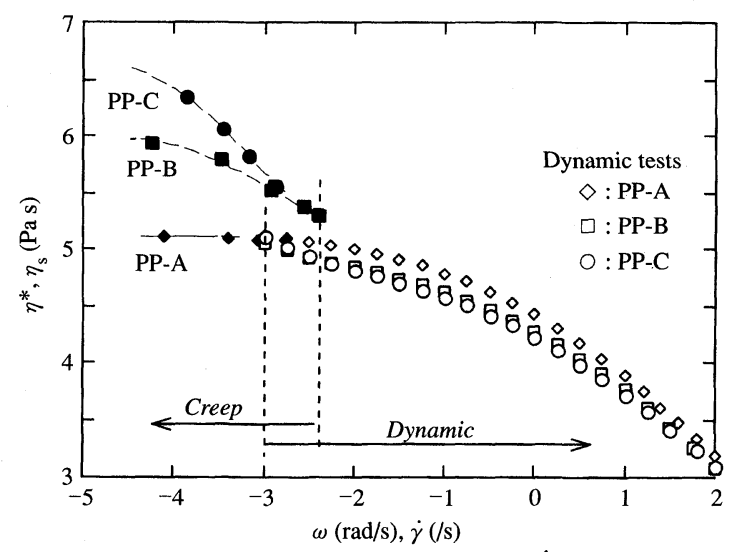

Fig. 6 Steady-state shear viscosity $\eta_{s}$ (closed symbols) and dynamic viscosity $\eta^{*}$ (open symbols) at $180^{\circ} \mathrm{C}$ for PP-A $(\diamond, \diamond), \operatorname{PP}-\mathrm{B}(\square, \square)$ and $\operatorname{PP}-\mathrm{C}(\boldsymbol{O}$, O)

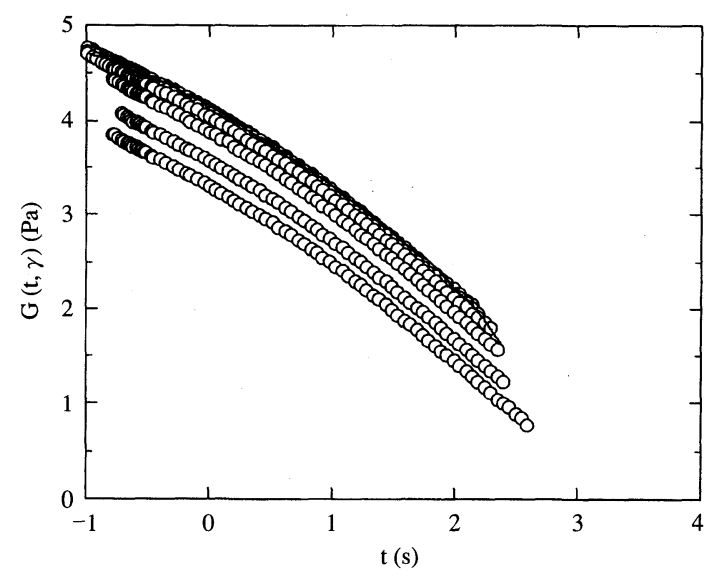

Fig. 7 Nonlinear relaxation modulus $G(t, \gamma)$ of the PP$A$ at $180^{\circ} \mathrm{C}$ for various strains: $0.3,0.5,0.7$, 1, 2, 4 and 6 from top to bottom. The solid curve represents the linear relaxation modulus $G(t)$ determined from the dynamic viscoelastic data 
空成形, ブロー成形などの自由表面を有する成形加工で PP の成形性が劣ることの大きな原因であるとされてきた. 発 泡成形の例をあげると, 従来の PP では, 押出発泡等の発 泡化プロセスにおいて, 樹脂中に溶解したガスが気泡とな り成長する際に破泡し, 独立気泡率が低下することにより 成形体の強度が低下する, 目的の発泡倍率が得られない, 成形品肉厚に薄肉部ができるなど, 期待される性能の発現 が困難であった。

図 10 に $\mathrm{PP}-\mathrm{A}, \mathrm{PP}-\mathrm{B}$ と $\mathrm{PP}-\mathrm{C}$ の一軸伸長粘度 $\left(\eta_{E}^{+}\right)$測定 結果を示す. $\mathrm{PP}-\mathrm{A}$ の $\eta_{E}^{+}$はさまざまなひずみ速度 $(\dot{\varepsilon})$ にお いてゆるやかな増加を示すのみである，図中の実線は $3 \eta^{+}$ を示す.ここで 和は2.3.2の動的粘弾性から求められた 線形粘度を表す． $\eta_{E}^{+}$はひずみ速度に依存せず，また線形 粘弾性則 $\left(\eta_{E}^{+}(t)=3 \eta^{+}(t)\right)$ に従うことがわかる ${ }^{25)}$. 同様に, 小さなひずみの範囲内では $\mathrm{PP}-\mathrm{B}$ および $\mathrm{PP}-\mathrm{C}$ の $\eta_{E}^{+}$も時 間に対して緩やかに増加する。しかし， PP-B と PP-C は ある時間（臨界ひずみ）から非常に強い粘度上昇, いわゆ るひずみ硬化性を示す. PP-B, PP-Cでは明らかに伸長流 動特性が改良されており, 従来の PP と比較すると劇的な 変化であることがわかる.これは, 図 4〜9において確認

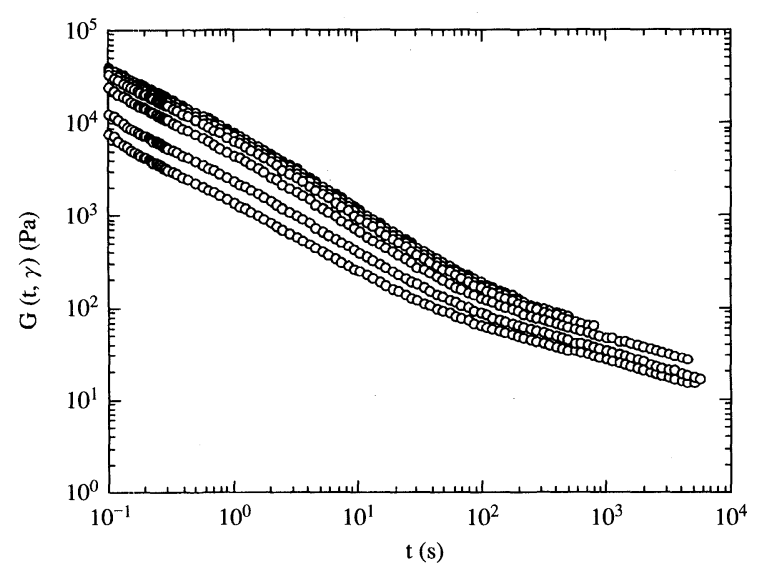

Fig. 8 Nonlinear relaxation modulus $G(t, \gamma)$ of the PP$\mathrm{C}$ at $180^{\circ} \mathrm{C}$ for various strains: $0.3,0.5,0.7$, $1,2,4$ and 6 from top to bottom

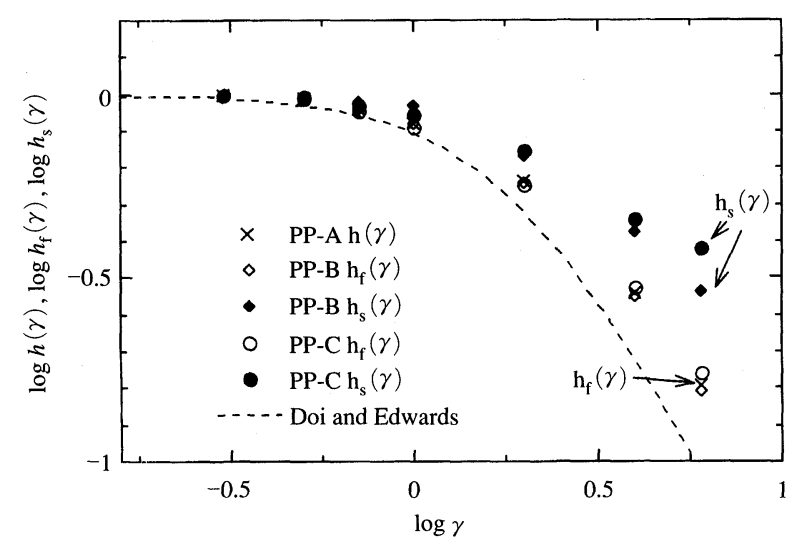

Fig. 9 Comparison of $h(\gamma)$ of PP-A and $h_{f}(\gamma)$ and $h_{s}(\gamma)$ for the fast and the slow relaxation process of PP-B, and PP-C obtained from Fig. 9 and Fig. 10. The symbols are designated in the figure. The solid line represents $h(\gamma)$ predicted by Doi and Edwards ${ }^{24)}$ for a monodisperse polymer
された長時間の緩和成分によってもたらされたものと考え られる。このひずみ硬化挙動は，はじめに述べたようにセ ルの変形過程の安定化のように伸長流動が支配的な成形加 工に拈いて有利な特性であろう。

\section{3. 成形性と成形品の特性}

重合段階で長時間緩和成分が導入された高溶融張力 PP は従来 PPにはない優れた溶融特性を有することを示した. ここでは，このような高溶融張力 PP を発泡成形に適用し た場合について簡単に御紹介したい.

\section{1 押出発泡特性}

試料は, MFR が 4 程度の従来 PP と高溶融張力 PPを 用いた。 ポリマーを溶融させるゾーンと冷却させるゾーン を持つ押出機を用いて押出発泡を行った結果を表 3 に示す. 従来 PP, 高溶融張力 PP ともに 10 倍発泡品である.また, これらの発泡シートの断面写真を図 11 に示す.従来 PP (図 11 (a))では, 独立気泡率は非常に低く，またセルの形状も 不均一であることが分かる. しかし優れた溶融特性を持つ 高溶融張力 PP では, 独立気泡率が高く, また発泡シート の強度も比較的高い. この発泡セルは図 $11(\mathrm{~b})$ に示した

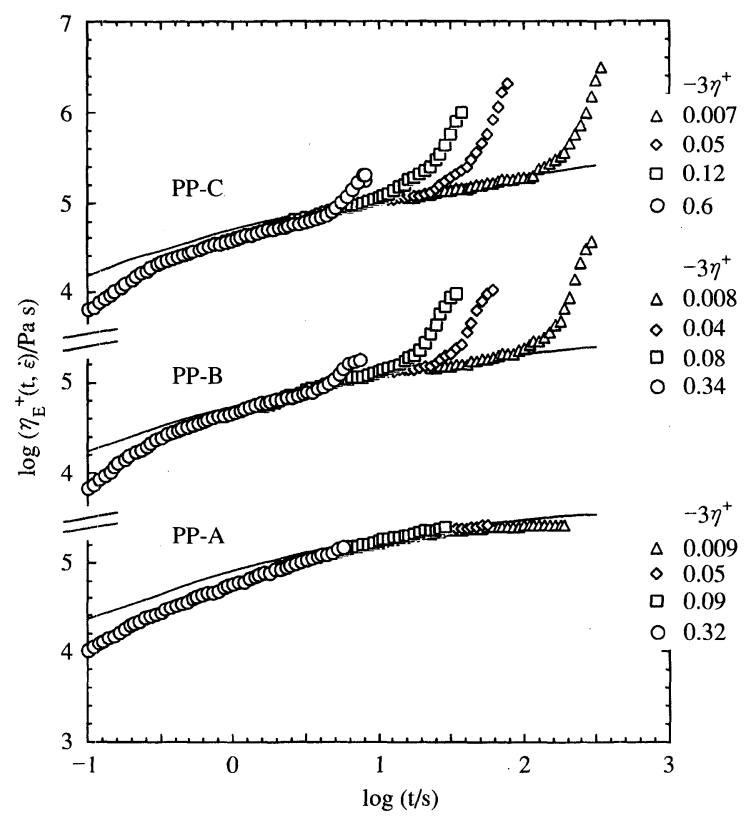

Fig. 10 Variation of transient uniaxial extensional viscosity with time at constant strain rates and temperature of $180^{\circ} \mathrm{C}$ for PP-A, and PP-B and PP.C. The solid lines indicate three times the dynamic viscosity, $3 \eta^{+}$, at $180^{\circ} \mathrm{C}$

Table 3 Results of extrusion foaming with physical agent

\begin{tabular}{lcc}
\hline & Conv. PP & NEWFOAMER \\
\hline MFR $(\mathrm{g} / 10 \mathrm{~min})$ & 4 & 4 \\
Expansion ratio & 10 & 10 \\
Apparent density $\left(\mathrm{g} / \mathrm{cm}^{3}\right)$ & 0.09 & 0.09 \\
$\begin{array}{l}\text { Volume fraction of closed } \\
\text { cell }(\%)\end{array}$ & 12 & 70 \\
Flexual strength $(\mathrm{MPa})$ & 1.5 & 2.3 \\
\hline
\end{tabular}

Physical agent:Butane 
ように，均一で破泡していない様子がわかる．高溶融張力 PP は伸長流動下におけるひずみ硬化性を有しており，ひ ずみに対する粘度の上昇が発泡セルの変形を安定化させ, 独立で均一なセルを形成することができたものと考えられ る.

また発泡シートを成形する際，高溶融張力 PP は高い溶 融張力とひずみ硬化性を有することによりドローダウンが 抑制され，さらには均一な肉厚の成形品が得られる等の特 徵がみられる。熱成形した成形品においても，その断面を 観察すると, 気泡はつぶれずに均一で緻密な形状を保って いることが確認された。

次に, 熱成形時の二次発泡特性を 2 倍発泡シート（化学

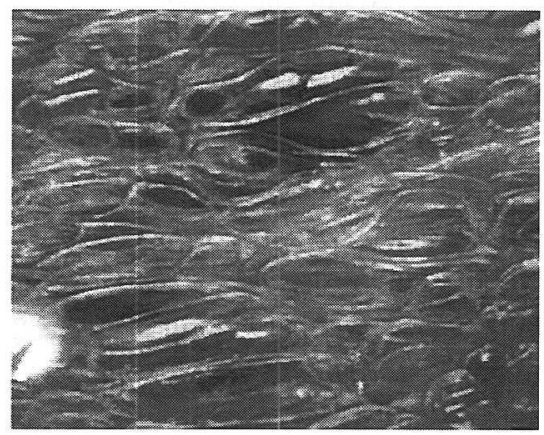

(a)

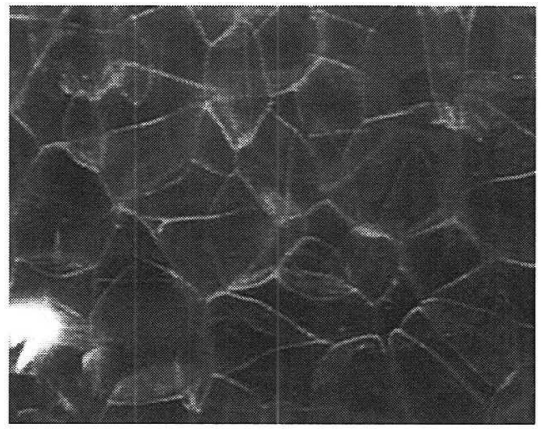

(b)

Fig. 11 Optical micrographs of foamed cell in the center of sheets: (a)conventional PP and (b) High Melt Strength PP with strong strain hardening.

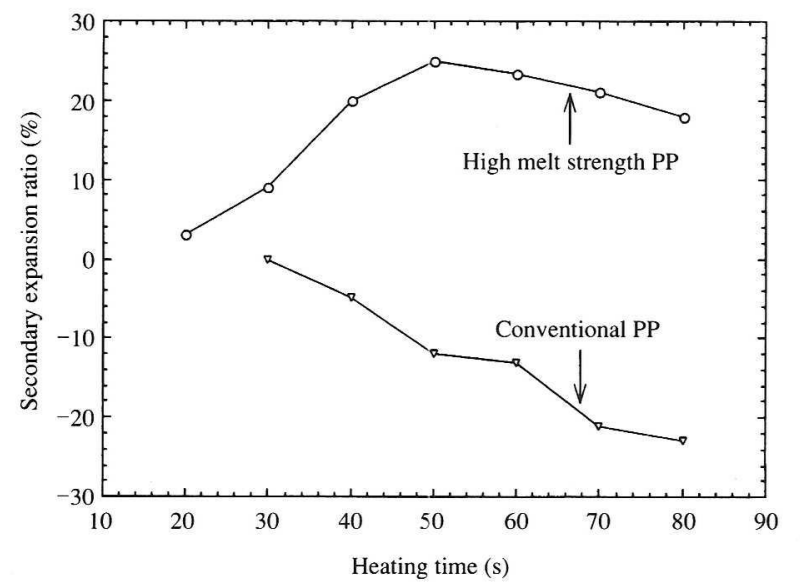

Fig. 12 Variation of expansion ratio with time at thermoforming process for High Melt Strength PP and conventional PP.
発泡）を加熱してシート厚み変化を測定することにより検 討した。図 12 に加熱時間に対する発泡率変化を示す. 図 11（b）に示した独立気泡を有する高溶融張力 PP では時間 とともにシート厚みが増加し, 二次発泡していることがわ かる. 従来 PPでは, 逆に加熱時間とともに厚みは減少し てしまう。

\section{2 リサイクル特性}

上述の押出ガス発泡の発泡製品や射出化学発泡品の何れ においても材料のリサイクル性は工業的に重要な特性の一 つである。押出成形や熱成形の現場では, 破材や熱成形後 の端材は押出機に戻され, 工程内のリサイクルが行われて いる.この場合, リサイクルされる材料が架橋または劣化 して流動性が大きく変化するとリサイクルが不能になった り, 加工条件をその都度変えなければならなくなる. 図 13 に高溶融張力 PP のリサイクル性評価結果を示す. 試料 は温度 $230^{\circ} \mathrm{C}$ の条件下で一軸押出機に 4 回通された. 重合 技術によって得られた高溶融張力 PP は熱的に安定であり, MFRの変動が小さいことが確認された.

\section{4.おわりに}

重合, 触媒技術によって得られた高溶融張力 PP は従来 の PPにはない溶融特性を持つことを示した。この樹脂は， レオロジー特性が制御されたことで高い成形加工性を備え, さらにリサイクル性などの実用物性にも優れる材料として の可能性を秘めている. 本稿では, おもに溶融樹脂のレオ ロジー特性と発泡成形性に絞って話を進めさせていただい た. 現在, ガスの溶解度や拡散係数, 核の生成, 成長過程, 加えて結晶化などと発泡成形性に関する研究が進められて おり，筆者らとしても読者諸兄のご協力, ご支援, ご指導 を仰ぎながら樹脂のさらなる改良と新たな PP 発泡の発展 の一助になるよう努力していきたい。

\section{謝辞}

レオロジー測定およびその解析技術につきまして御指導い ただきました山形大学工学部小山清人教授, 瀧本淳一助教 授, 增㴊雄一助手, 西岡昭博博士ならびに小山研究室の方々 に心より感謝いたします。

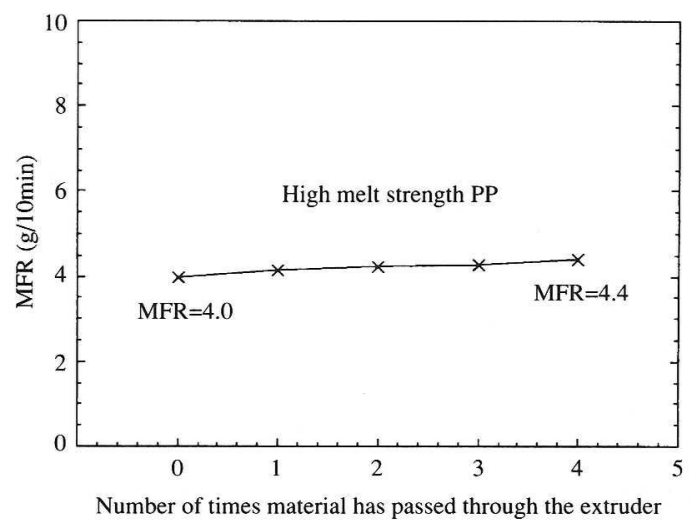

Fig. 13 Effect of repeating recycling of High Melt Strength PP on MFR. Sample was re-extruded at $230^{\circ} \mathrm{C}$ via a single-screw extruder. 


\section{参 考 文 献}

1 ) Osakada, A. and Koyama, M. : Jpn. Chem. Quartery, 5, 55 (1969)

2 ) Park, C. B. : Polym. Eng. and Sci., 36(1), 35 (1996)

3 ) Satou, Y., Fujiwara, K., Takikawa, T., Sumarno, Takishima, S. and Masuoka, H. : Fluid Phase Equilibria, 162, 261（1999）

4 ）大嶋正裕 : 成形加工シンポジア '00, B 201（2000）

5 ）例えば, 特公平 1-12770.

6 ) U. S. Patent, 4916198, Himont Inc.

7 ) Yoshii, F., Makuuchi, K., Kikukawa, S., Tanaka, T., Saitoh, J. and Koyama, K. : J. Appl. Polym. Sci., 60, 617 (1996)

8 ) Wong, B. and Baker, W. E. : Polymer, 38, 2781 (1997)

9 ) Murata, T., Noma, T., Takimoto, J. and Koyama, K. : 14 th International Annual Meeting, Polymer Processing Society, Yokohama, Jpn, G 4-P 05, (1998)

10) Sugimoto, M., Tanaka, T., Masubuchi, Y., Takimoto, J. and Koyama, K. : J. Appl. Polym. Sci., 73, 1493 (1999)

11）例えば, 特開平 7-330935.

12）小山清人，石塚 修：日本レオロジー学会誌，13，93 (1985)

13) Minegishi, A., Naka, Y., Takahashi, T., Masubuchi, Y., Takimoto, J. and Koyama, K. : Nihon Reoroji Gak- kaishi, 25, 215 (1997)

14) Koyama, K., Takahashi, T., Naka, T. and Takimoto, $\mathrm{J} .: 13$ th International Annual Meeting, Polymer Processing Society, Hoboken, NJ, 8 B (1997)

15）大嶋正裕：成形加工シンポジア，B 201（2000）

16) Ferry, J. D. : Viscoelastic properties of polymers (1980), John Wiley \& Sons.

17) Soskey, P. R. and Winter, H.H. : J. Rheol., 28, 625 (1984)

18) Meissner, J. : Rhel. Acta, 8, 78 (1969)

19) Kurzbeck, S., Oster, F. and Munstedt, H. : J. Rheol., 43, 359 (1999)

20) Tschoegl, N. W.: The theory of linear viscoelastic behavior (1981), Academic Press.

21) Laun, H. M. : Rheol. Acta, 17, 1 (1978)

22) Yoshikawa, K., Toneaki, N., Moteki, Y., Takahashi, M. and T. Masuda:Nihon Reoroji Gakkaishi, 18, 80 (1990)

23) Osaki, K. : Rhel. Acta, 32, 429 (1993)

24) Doi, M. and Edwards, S. F. : The theory of polymer $d y$ namics (1986), Oxford University.

25) Trouton, F. T.: Proceedings of the Royal Society, A 77, 426. 